\title{
Oviposition of fruit flies (Diptera: Tephritidae) and its relation with the pericarp of citrus fruits
}

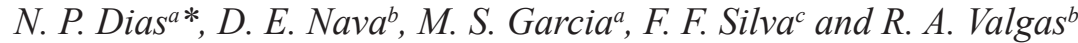 \\ aPrograma de Pós-graduação em Fitossanidade, Universidade Federal de Pelotas - UFPel, \\ Campus Universitário, s/n, CEP 96900-010, Capão do Leão, RS, Brazil \\ bLaboratório de Entomologia, Empresa Brasileira de Pesquisa Agropecuária - Embrapa, \\ Rodovia BR-392, Km 78, CEP 96010-970, Pelotas, RS, Brazil \\ 'Laboratório de Entomologia, Universidade Federal do Pampa - UNIPAMPA, \\ Av. Luiz Joaquim de Sá Britto, s/n, CEP 97650-000, Itaqui, RS, Brazil \\ *e-mail: nayma.dias@gmail.com
}

Received: August 8, 2016 - Accepted: March 7, 2017 - Distributed: October 31, 2018

\begin{abstract}
Fruit flies (Diptera: Tephritidae) represent a threat to fruit growing worldwide, mainly the citrus culture, however, biological studies show that fruit flies are not perfectly adapted to this host. This study investigated oviposition of Anastrepha fraterculus (Wiedemann, 1830) and Ceratitis capitata (Wiedemann, 1824) and its relation with the pericarp of citrus fruits. We evaluated the relationship between depth of oviposition of A. fraterculus and C. capitata and epicarp thickness of orange [Citrus sinensis (L.) Osbeck)] 'Navelina' and tangerine [C. reticulata (L.)] 'Clemenules' and the influence of fruit mesocarp of tangerine 'Clemenules' on oviposition of these species. The study was conducted under controlled conditions of temperature $\left(25 \pm 2{ }^{\circ} \mathrm{C}\right)$, relative humidity $(70 \pm 10 \% \mathrm{RH})$ and photophase $(12 \mathrm{~h})$. A. fraterculus and C. capitata laid their eggs in the flavedo region of orange 'Navelina' and between the albedo and flavedo of tangerine 'Clemenules'. When fruits with mesocarp exposed were offered, there was no oviposition by both fruit fly species. The results show that epicarp thickness of citrus fruits did not influence oviposition of $A$. fraterculus and C. capitata as oviposition did not occur only in the presence of the mesocarp, suggesting that other factors are involved in oviposition of these species.
\end{abstract}

Keywords: Anastrepha fraterculus, Ceratitis capitata, citrus peel structure, epicarp, mesocarp.

\section{Oviposição de moscas-das-frutas (Diptera: Tephritidae) e sua relação com o pericarpo de frutos cítricos}

\section{Resumo}

As moscas-das-frutas (Diptera: Tephritidae) representam um risco à fruticultura mundial, especialmente na cultura dos citros, entretanto estudos biológicos demonstram que as moscas-das-frutas não estão perfeitamente adaptadas à estes hospedeiros. Este estudo investigou a oviposição de Anastrepha fraterculus (Wiedemann, 1830) e Ceratitis capitata (Wiedemann, 1824) e sua relação com o pericarpo de frutos cítricos. Foi avaliada a relação entre a profundidade de oviposição de A. fraterculus e de C. capitata e a espessura do epicarpo dos frutos de laranjeira [Citrus sinensis (L.) Osbeck)] 'Navelina' e tangerineira [C. reticulata (L.)] 'Clemenules' e a influência do mesocarpo de frutos de tangerineira 'Clemenules' na oviposição destas espécies. O estudo foi conduzido em condições controladas de temperatura $\left(25 \pm 2{ }^{\circ} \mathrm{C}\right)$, umidade relativa $(70 \pm 10 \%)$ e fotofase (12 horas). A. fraterculus e C. capitata depositaram ovos no flavedo de frutos de laranjeira 'Navelina' e entre o flavedo e o albedo de frutos de tangerineira 'Clemenules'. Quando oferecido frutos com mesocarpo exposto, não houve oviposição por ambas as espécies de mosca. Os resultados demonstram que a espessura do epicarpo de frutos cítricos não influenciou a oviposição de $A$. fraterculus e de $C$. capitata, a qual não ocorreu na presença apenas do mesocarpo, sugerindo que outros fatores estão envolvidos na oviposição por estas espécies.

Palavras-chave: Anastrepha fraterculus, Ceratitis capitata, estrutura da casca de citros, epicarpo, mesocarpo.

\section{Introduction}

Citrus hosts a large number of pests worldwide, and of these, Tephritidae fruit flies may represent major pests (Onah et al., 2015). The South American fruit fly,
Anastrepha fraterculus (Wiedemann, 1830) and the Mediterranean fruit fly, Ceratitis capitata (Wiedemann, 1824) (Diptera: Tephritidae) are reported as the most 
common fruit fly pests attacking citrus in Brazil (Silva et al., 2006; Paiva and Parra, 2013).

The selection of oviposition site of fruit flies is critical for survival and success of their offspring (Díaz-Fleischer et al., 2000). In the citrus culture, while fruit flies are considered major pests and causing economic losses (Muthuthantri and Clarke, 2012), many authors believe that fruit files are not perfectly adapted to development in citrus fruits (Salvatore et al., 2004). For Back and Pemberton (1915), this lower performance could be related to resistance mechanisms of citrus fruits, such as chemical components of glands in the flavedo (epicarp) and albedo (mesocarp) elasticity that could generate mechanical resistance and consequently hinder embryonic and larval development. Other factors that affect performance for oviposition in citrus fruits comprise the gum produced by varieties of grapefruit (C. aradise) (Macfad), lime [C. aurantifolia (Christmas) Swingle] and lemon $[(C$. limon) (L. Burm) $]$ (Rutaceae) and the hardening of tissues around the oviposition hole.

Susceptibility of citrus to fruit flies varies according to the fly species, fruit maturity, fruit species and cultivar, oviposition behavior of the insect and consistency of the fruit peel are factors possibly involved in this process (Greany et al., 1983). Females of fruit flies consider qualitative and quantitative aspects of the citrus fruit composition in the selection process for an oviposition site. However, the exact location where females tend to lay their eggs in citrus fruits as well as the effects of the physical characteristics of these fruits on oviposition remain unknown. Prokopy and Vargas (1996) believe that epicarp thickness of citrus fruits could be an important criterion in infestation of fruit flies. Thus, the host range of tephritid fruit flies may be restricted by the ability of the insect to penetrate the peel of the host fruit (Rattanapun et al., 2009, 2010). Thus, this study investigated oviposition of $A$. fraterculus and C. capitata and its relation with the pericarp of citrus fruits.

\section{Material and Methods}

The study was conducted in Pelotas, Rio Grande do Sul State, Brazil, under controlled conditions of temperature $\left(25 \pm 2{ }^{\circ} \mathrm{C}\right)$, relative humidity $(70 \pm 10 \% \mathrm{RH})$ and photophase $(12 \mathrm{~h})$.

\subsection{Maintenance rearing}

The population of $A$. fraterculus was reared in mango (Mangifera indica L.) (Anacardiaceae) while C. capitata was reared in papaya (Carica papaya L.) (Caricaceae). The fruits were exposed to the flies for oviposition for a period of $24 \mathrm{~h}$, when the fruits were removed and packed in plastic containers $(11 \times 12 \times 19 \mathrm{~cm})$ covered with TNT fabric (non-woven fabric). The containers were lined with a fine vermiculite texture and after pupation, the insects were transferred to Petri dishes $(10 \times 1.5 \mathrm{~cm})$ containing moistened vermiculite where they remained until emergence. The adult insects were kept in wooden cages $(50 \times 50 \times 40 \mathrm{~cm})$ lined with voile fabric and with a side opening for maintenance. The adults were fed with a solid diet composed of sugar, wheat germ and yeast at ratio $3: 1: 1$ in a plastic container $(50 \mathrm{~mL})$.

\subsection{Depth of oviposition and its relation to epicarp thickness}

Fruits of orange [Citrus sinensis (L. Osbeck)] 'Navelina' and tangerine 'Clemenules' (Rutaceae) were offered to females of A. fraterculus and C. capitata. For control, fruits of papaya 'Solo Golden' (Carica papaya L.) (Caricaceae), mango 'Tommy Atkins' (Mangifera indica L.) (Anacardiaceae) and guava 'Paluma' (Psidium guajava L.) (Myrtaceae) were offered because they are natural hosts and used for lab rearing (Fernandes-da-Silva and Zucoloto, 1993; Joachim-Bravo and Silva Neto, 2004; Aluja et al, 2014). All fruits used in the experiments were ripe according to the outside color of the peel for each cultivar (Malevski et al., 1977; Bron and Jacomino, 2006; Cavalini et al., 2006; Lado et al., 2014).

The fruits were individually exposed in the bottom plastic cages $(24 \times 12 \times 17 \mathrm{~cm})$ with 10 females of $15 \mathrm{~d}$ of age for a period of $24 \mathrm{~h}$. After the exposure period, the fruits were removed and cut into thin slices $(10 \mathrm{~mm})$ perpendicular to the fruit surface using a scalpel. After, they were analyzed under a stereoscopic microscope with $10 \mathrm{x}$ magnification (Model Stemi SV 11, Zeiss, Thornwood, NY) to identify the location of eggs in each fruit. The measurements were performed by determining the distance $(\mathrm{mm})$ of the front pole of the egg to the fruit surface, as described by Perondini et al. (1998). Epicarp thickness ( $\mathrm{mm}$ ) of each fruit host was determined using a digital caliper (Model Hardened, Shainless ${ }^{\circledR}$, China) with 10 repetitions for each fruit specie. For citrus fruit, besides epicarp (flavedo) thickness ( $\mathrm{mm})$, mesocarp (albedo) thickness was also measured and peel thickness consisted of the sum of the two measurements.

To express the insertion degree of the ovipositor regarding fruit peel thickness, we used an index calculated by, where: $I=$ insertion index, that is, the number of times the ovipositor exceeded peel thickness and laid egg (s); o = distance between the front pole of the egg to fruit surface (mm); e = peel thickness (mm). In this index, when $I$ is greater than $1(I>1)$, it was considered that the ovipositor surpassed the entire peel.

For both species of fruit fly, it was determined the total aculeus length $(\mathrm{mm})$ from samples of 10 females kept in alcohol $70^{\circ}$. For these measurements, the aculeus was extended, removed from the eversible membrane and analyzed in stereoscopic microscope with $10 \mathrm{x}$ magnification (Model Stemi SV 11, Zeiss, Thornwood, NY).

The experiment was conducted in completely randomized design with five treatments (different fruit species) and 10 repetitions (fruit). Data on oviposition depth and peel thickness ( $\mathrm{mm}$ ) of each host fruit were submitted to the Pearson linear correlation ( $\mathrm{r}$ ) through resampling (bootstrap) with 5000 simulations (BioEstat 5.3). 


\subsection{Influence of mesocarp of tangerine fruit on oviposition}

Four substrates were offered to females of $A$. fraterculus and $C$. capitata for oviposition. The substrates consisted of tangerines 'Clemenules': 1) whole fruit; 2) fruit without epicarp; 3) fruit without epicarp covered with Parafilm ${ }^{\circledR}$ (Kasvi, Curitiba, Brazil); and 4) only epicarp cut into $8 \mathrm{~cm}$ diameter circle $\times 0.32 \mathrm{~cm}$ thick. The substrates were offered in plastic cages $(24 \times 12 \times 17 \mathrm{~cm})$ to 10 females of $15 \mathrm{~d}$ of age for a period of $24 \mathrm{~h}$. After exposure, the substrates were removed and analyzed under a stereoscopic microscope with $10 \mathrm{x}$ magnification (Model Stemi SV 11, Zeiss, Thornwood, NY) to count the eggs.

The experiment was conducted in completely randomized design with four treatments (substrate type) and 10 repetitions (substrate). The data on the average number of eggs in each substrate were tested for normality by the Shapiro-Wilk test $(p \leq 0.05)$. The means were subjected to analysis of variance using the Kruskal-Wallis test $(p \leq 0.05)$ followed by the Dunn test $(p \leq 0.05)$ (BioEstat 5.3 ).

\section{Results}

\subsection{Depth of oviposition and its relation to epicarp thickness}

For A. fraterculus, there was no significant correlation between the insertion depth and epicarp thickness in any of the hosts $(p>0.05)$. C. capitata presented a significant correlation and directly proportional in mango $(p=0.0328)$.

The largest number of eggs was obtained in mango for A. fraterculus and in papaya for C. capitata (Table 1). The insertion index was higher in mango than in the other hosts, that is, the ovipositor exceeded epicarp thickness more than 16 times for $C$. capitata and 14 times for $A$. fraterculus (Table 1). For papaya and guava, the insertion indexes were lower than in mango. In citrus fruits, insertion indexes for both orange and tangerine were the lowest among all hosts evaluated (Table 1).

For both fruit fly species, the ovipositor did not completely surpass the flavedo in orange $(I<1)$, but for A. fraterculus, the ovipositor surpassed the flavedo $(I>1)$, however, it did not exceed the albedo in tangerine $(I<1)$ reaching only $0.07 \mathrm{~mm}$ (oviposition depth minus flavedo thickness) (Table 2). Similar situation for C. capitata, which reached only $0.08 \mathrm{~mm}$ of the albedo (Table 2).

\subsection{Influence of fruit mesocarp of tangerine fruit on oviposition}

Significant difference was observed for oviposition among tangerine substrates for A. fraterculus $(\mathrm{H}=25.18$, $\mathrm{gl}=3, p<0.0001)$ and $C$. capitata $(\mathrm{H}=23.97, \mathrm{gl}=3$, $p<0.0001)$. The number of eggs of $A$. fraterculus and C. capitata differed significantly when different substrates for oviposition were offered (Table 3). Oviposition occurred for A. fraterculus and C. capitata when the whole tangerine fruit and fruit with epicarp exposed cut in a circle were offered to the ovipositors, differing significantly from the other treatments where oviposition did not occur.

\section{Discussion}

Epicarp thickness of oranges 'Navelina' and tangerine 'Clemenules' did not influence oviposition of $A$. fraterculus and $C$. capitata. The insects laid eggs in the flavedo region of orange 'Navelina' and between the albedo and flavedo in tangerine 'Clemenules'. These data corroborate the results obtained by Papachristos and Papadopoulos (2009). The authors found no correlation between fecundity of C. capitata in citrus fruits and their physical characteristics such as epicarp thickness.

Table 1. Number of eggs, oviposition depth (mm), peel thickness (mm), flavedo and albedo thickness $(\mathrm{mm})( \pm \mathrm{SD})$ and insertion index $(I)$ in five fruits for Anastrepha fraterculus and Ceratitis capitata. Temperature $25 \pm 2{ }^{\circ} \mathrm{C}, 70 \pm 10 \% \mathrm{RH}$ and photophase of $12 \mathrm{~h}$.

\begin{tabular}{|c|c|c|c|c|c|}
\hline \multirow[t]{2}{*}{ Fruit specie $^{a}$} & $\begin{array}{c}\text { Total number } \\
\text { of eggs }\end{array}$ & $\begin{array}{l}\text { Oviposition } \\
\text { depth }(\mathrm{mm})\end{array}$ & $\begin{array}{l}\text { Peel thickness } \\
\text { (mm) }\end{array}$ & $\begin{array}{l}\text { Flavedo/Albedo thickness } \\
(\mathbf{m m})^{\mathrm{b}}\end{array}$ & $\begin{array}{l}\text { Insertion } \\
\text { index }(I)^{\mathrm{c}}\end{array}$ \\
\hline & \multicolumn{5}{|c|}{ Anastrepha fraterculus } \\
\hline Papaya & $42 \pm 1.87$ & $0.72 \pm 0.06$ & $0.49 \pm 0.04$ & - & 1.46 \\
\hline Mango & $169 \pm 4.30$ & $2.63 \pm 0.25$ & $0.19 \pm 0.03$ & - & 14.09 \\
\hline Guava & $53 \pm 2.16$ & $5.74 \pm 0.18$ & $4.86 \pm 0.25$ & - & 1.18 \\
\hline Orange & $35 \pm 1.43$ & $0.15 \pm 0.09$ & $2.68 \pm 0.16$ & $(0.60 \pm 0.10 / 2.08 \pm 0.17)$ & 0.05 \\
\hline \multirow[t]{2}{*}{ Tangerine } & $61 \pm 1.96$ & $1.56 \pm 0.14$ & $2.11 \pm 0.14$ & $(1.49 \pm 0.10 / 0.62 \pm 0.09)$ & 0.74 \\
\hline & \multicolumn{5}{|c|}{ Ceratitis capitata } \\
\hline Papaya & $178 \pm 4.02$ & $1.35 \pm 0.10$ & $0.49 \pm 0.04$ & - & 2.74 \\
\hline Mango & $60 \pm 0.81$ & $3.06 \pm 0.19$ & $0.19 \pm 0.03$ & - & 16.36 \\
\hline Guava & $43 \pm 1.25$ & $5.57 \pm 0.13$ & $4.86 \pm 0.25$ & - & 1.15 \\
\hline Orange & $57 \pm 1.25$ & $0.26 \pm 0.39$ & $2.68 \pm 0.16$ & $(0.60 \pm 0.10 / 2.08 \pm 0.17)$ & 0.10 \\
\hline Tangerine & $55 \pm 1.84$ & $1.57 \pm 0.15$ & $2.11 \pm 0.14$ & $(1.49 \pm 0.10 / 0.62 \pm 0.09)$ & 0.74 \\
\hline
\end{tabular}

${ }^{a}$ Cultivars: papaya Solo 'Golden', mango 'Tommy Atkins', guava 'Paluma', orange 'Navelina' and tangerine 'Clemenules'; ${ }^{b}$ Segments of citrus peel; ${ }^{c}$ Insertion index $(I)$ obtained from the relationship between oviposition depth $(\mathrm{mm})$ and peel thickness ( $\mathrm{mm}$ ). 
Table 2. Insertion index $(I)$ and average of aculeus length $( \pm \mathrm{SD})$ of Anastrepha fraterculus and Ceratitis capitata in flavedo (epicarp) and albedo (mesocarp) of citrus fruits. Temperature $25 \pm 2{ }^{\circ} \mathrm{C}, 70 \pm 10 \% \mathrm{RH}$ and photophase of $12 \mathrm{~h}$.

\begin{tabular}{|c|c|c|c|}
\hline \multirow{2}{*}{ Fruit } & \multicolumn{2}{|c|}{ Insertion index $(l)$} & Aculeus length (mm) \\
\hline & \multicolumn{2}{|c|}{ Anastrepha fraterculus } & $1.56 \pm 0.15$ \\
\hline & Flavedo & Albedo & - \\
\hline Orange 'Navelina' & 0.25 & 0.00 & - \\
\hline \multirow[t]{3}{*}{ Tangerine 'Clemenules' } & 1.07 & 0.17 & - \\
\hline & \multicolumn{2}{|c|}{ Ceratitis capitata } & $1.33 \pm 0.19$ \\
\hline & Flavedo & Albedo & - \\
\hline Orange 'Navelina' & 0.43 & 0.00 & - \\
\hline Tangerine 'Clemenules' & 1.08 & 0.19 & - \\
\hline
\end{tabular}

Table 3. Average number of eggs ( \pm SD) of Anastrepha fraterculus and Ceratitis capitata in tangerine 'Clemenules'. Temperature $25 \pm 2{ }^{\circ} \mathrm{C}, 70 \pm 10 \% \mathrm{RH}$ and photophase of $12 \mathrm{~h}$.

\begin{tabular}{lcc}
\hline \multirow{1}{*}{ Substrate } & \multicolumn{2}{c}{ Number of eggs } \\
\cline { 2 - 3 } & $\begin{array}{c}\text { Anastrepha } \\
\text { fraterculus }\end{array}$ & $\begin{array}{l}\text { Ceratitis } \\
\text { capitata }\end{array}$ \\
\hline Whole fruit & $3.9 \pm 1.10 \mathrm{a}$ & $2.6 \pm 1.34 \mathrm{a}$ \\
Fruit epicarp & $0.0 \pm 0.00 \mathrm{~b}$ & $0.0 \pm 0.00 \mathrm{~b}$ \\
Fruit without covered & $0.0 \pm 0.00 \mathrm{~b}$ & $0.0 \pm 0.00 \mathrm{~b}$ \\
epicarp & & \\
Epicarp cut in circles & $1.1 \pm 1.10 \mathrm{ab}$ & $2.3 \pm 1.25 \mathrm{a}$ \\
\hline Values followed by different letters in column differ by the \\
Dunn test $(p \leq 0.05)$.
\end{tabular}

The larger number of eggs of $A$. fraterculus obtained in mango and $C$. capitata from papaya may be related to "pre-imaginal conditioning", since the insects used in the experiment were reared in this host. The highest insertion index obtained in mango may have occurred due to the smaller peel thickness of these fruits $(0.19 \mathrm{~mm})$ compared to other treatments, since there was no significant correlation between peel thickness and the number of eggs of C. capitata.

In papaya, the lower insertion index estimated for C. capitata compared to the indexes obtained for mango fruit can be related to the presence of benzyl isothiocyanate (BITC) in fruit. This substance is present at high concentrations in unripe papaya fruit and decreases as the fruit ripens, suggesting that only ripe fruits are infested in the field, however, at a smaller number of $A$. fraterculus (Seo et al., 1983). This data indicates that C. capitata can be less affected by BITC, corroborating the results presented by Joachim-Bravo and Silva Neto (2004) who reported preference for papaya fruit for oviposition of C. capitata, followed by mango and orange, confirming the data obtained in this study (Table 1).

In guava, the lowest index estimated for papaya and mango fruits may be attributed to the influence of fruit chemical characteristics, such as $\mathrm{pH}$ and soluble solids ( ${ }^{\circ}$ Brix) as described by Branco et al. (2000). In these fruits, the larger number of eggs of $A$. fraterculus may have occurred due to its preference for native fruit, unlike
C. capitata, which also infests native fruits but prefers mainly exotic hosts (Branco et al., 2000).

The lower insertion index in orange compared to other treatments may indicate that this host has increased resistance to infestation of fruit flies even compared to tangerine (Table 1). Papachristos and Papadopoulos (2009) evaluated five citrus cultivars (orange 'Newhall', orange 'Merlin', orange 'Xino Artas', tangerine 'Arta' and lemon 'Maglini') and found that females of C. capitata failed to lay eggs inside the fruit.

The lower consistency of tangerine peel can also be considered a key factor in fruit susceptibility to the attack of A. fraterculus. According to Branco et al. (2000), in addition to reduction on essential oil contents, peel firmness decreases allowing higher larval survival due to lower difficulty of the larva to migrate from peel to pulp. The results of this study corroborate the work performed by Greany et al. (1983) that found tangerines more susceptible to the attack of Anastrepha suspensa (Loew) than orange and lemon.

The higher insertion index of $C$. capitata in orange, although did not exceed the flavedo region, may have occurred due to the greater number of eggs, since the aculeus length of this species is shorter than that of $A$. fraterculus (Tables 1 and 2). Branco et al. (2000) report that when females lay several eggs in the same region of the fruit, as it occurs for C. capitata, there may be a breakdown in fruit resistance allowing at least part of the eggs to develop.

The data obtained show that peel thickness of citrus fruits does not influence oviposition depth of $C$. capitata and $A$. fraterculus and that other factors may be involved in this process. The flavedo constitution is cited by several authors as the most critical resistance mechanism to fruit flies infestation in citrus (Back and Pemberton, 1915; Greany et al., 1983; Salvatore et al., 2004; Ioannou et al., 2012). Possibly, when oil glands in the flavedo are broken, they release toxic compounds that, in contact with eggs and first instar larvae, can cause death before the larvae reach the albedo region (non-oily region of the peel) (Greany, 1989).

C. capitata laid eggs at greater depth in orange and tangerine compared to A. fraterculus (Table 1). Back and Pemberton (1915) reported that when ovipositing at greater depth, females ensure the survival of their offspring 
by not exposing the eggs to essential oil glands in the flavedo. Greany et al. (1983) reported that egg viability of $A$. suspensa laid between the oil glands in the flavedo region was greater than that of eggs deposited directly in the glands.

Oil toxicity in the flavedo region for eggs and larvae of C. capitata can be attributed to the higher content of limonene in oranges (Papachristos et al., 2009). Salvatore et al. (2004) evaluated egg viability of $C$. capitata laid in epicarp of four orange cultivars and found values between 19 and $49 \%$ of viability. The same authors found that citral compounds, coumarin and linalool, extracted from lime 'Sicilian' caused mortality of larvae of C. capitata of up to $98 \%$.

The presence of chorion reticulation as well as respiratory appendages, common in fly eggs, could also be an adaptation of these insects. Murillo and Jirón (1994) found that $A$. obliqua showed greater oxygen demand by depositing their eggs in a way that the respiratory appendages remain outside of the fruit. However, Margaritis (1985) believes that species such as $A$. serpentina and C. capitata can oviposit in greater depth due to an air chamber in eggs, which would not require immediately atmospheric oxygen. This discussion could explain oviposition of A. fraterculus and C. capitata (Table 1), since C. capitata oviposited deeper, when compared to $A$. fraterculus, except for guava fruit.

Another interesting discussion is related to the hatching region of larvae. According to Ferrar (1987), the hatching of larvae of $C$. capitata occurs through a longitudinal oviposition slit starting at the front end of the egg. Conversely, in A. fraterculus the oviposition slit is located in the posterior third of the egg (Selivon et al., 1996). This fact suggests that oxygen demand may also be a factor considered at oviposition time, since the two species of fruit flies studied did not oviposit their eggs inside the citrus fruits (Table 2).

When we assessed the influence of substrate on oviposition of $A$. fraterculus and C. capitata, we observed that there was no oviposition in substrates with mesocarp only (fruit without epicarp and fruit without epicarp covered with Parafilm ${ }^{\circledR}$ ) (Table 3). These data suggest that epicarp (flavedo) of citrus fruits, despite containing toxic compounds for immature insects, has in its composition attractive substances to adult females (kairomone). Adult Tephritidae can detect volatile compounds of fruits several meters away and these stimuli are used for orientation toward the host plant (McInnis, 1989).

The fruit is chosen based on color, shape, size and volatile compounds is releases (Aluja and Prokopy, 1992). Odors emitted by fruits influence mating, feeding and oviposition (Landolt et al., 1992). Thus, these odors can stimulate higher or lower attractiveness due to age, mating status and insect experience with the host (Quilici et al., 2014).

Thus, by removing this interspecific chemical communication, there was no oviposition in the fruits without epicarp. This fact was observed by Ioannou et al. (2012) who identified that compounds like linalool, found in different contents in citrus, is associated with mortality of immature stages of $C$. capitata, while limonene, found in more than $90 \%$ in all citrus oils, stimulates oviposition justifying infestations of $C$. capitata in citrus fruits.

Further studies are needed to evaluate the different hypotheses considered in this work. Studies on Tephritidae embryology and analyses of the oil glands in the flavedo region during oviposition as well as studies on comparative of toxicity of compounds that act on the oviposition behavior of these insects would help to answer these questions.

\section{Acknowledgements}

The authors wish to thank National Counsel of Technological and Scientific Development (CNPq), Coordination for the Improvement of Higher Education Personnel (CAPES) and the Brazilian Agricultural Research Corporation (EMBRAPA), for the financial support and scholarship.

\section{References}

ALUJA, M. and PROKOPY, R.J., 1992. Host search behavior of Rhagoletis pomonella flies: Inter-tree movement patterns in response to wind-bourne fruit volatiles under field conditions. Physiological Entomology, vol. 17, no. 1, pp. 1-8. http://dx.doi. org/10.1111/j.1365-3032.1992.tb00983.x.

ALUJA, M., ARREDONDO, J., DIAZ-FLEISCHER, F., BIRKE, A., RULL, J., NIOGRET, J. and EPSKY, N., 2014. Susceptibility of 15 mango (Sapindales: Anacardaceae) cultivars to the attack by Anatrepha ludens and Anatrepha obliqua (Diptera: Tephritidae) and the role of underdeveloped fruit as pest reservoirs: Management implications. Journal of Economic Entomology, vol. 107, no. 1, pp. 375-388. PMid:24665723. http://dx.doi.org/10.1603/EC13045.

BACK, E.A. and PEMBERTON, C.E., 1915. Susceptibility of citrus fruits to the attack of the Mediterranean fruit fly. Journal of Agricultural Research, vol. 1, no. 4, pp. 311-330.

BRANCO, E.S., VENDRAMIM, J.D. and DENARDI, F., 2000. Resistance to the fruit flies in fruit trees. In: A. MALAVASI and R.A. ZUCCHI, eds. Fruit flies of economic importance: from basic to applied knowledge. Ribeirão Preto: Holos, pp. 161-168.

BRON, I.U. and JACOMINO, A.P., 2006. Ripening and quality of 'Golden' papaya fruit harvested at different maturity stages. Brazilian Journal of Plant Physiology, vol. 18, no. 3, pp. 389-396. http://dx.doi.org/10.1590/S1677-04202006000300005.

CAVALINI, F.C., JACOMINO, A.P., LOCHOSKI, M.A., KLUGE, R.A. and ORTEGA, E.M.M., 2006. Maturity indexes for 'Kumagai' and 'Paluma' guavas. Revista Brasileira de Fruticultura, vol. 28, no. 2, pp. 176-179. http://dx.doi.org/10.1590/ S0100-29452006000200005.

DÍAZ-FLEISCHER, F., PAPAJ, D.R., PROKOPY, R.J., ALUJA, M. and NORRBOM, A.L., 2000. Evolution of fruit fly oviposition behavior. In: M. ALUJA and A.L. NORRBOM, eds. Fruit flies (Tephritidae): phylogeny and evolution of behavior. Boca Raton: CRC Press, pp. 811-841.

FERNANDES-DA-SILVA, P.G. and ZUCOLOTO, F.S., 1993. The influence of host nutritive value on the performance and food selection in Ceratitis capitata (Diptera, Tephritidae). Journal of Insect Physiology, vol. 39, no. 10, pp. 883-887. http://dx.doi. org/10.1016/0022-1910(93)90121-7. 
FERRAR, P., 1987. A guide to the breeding habits and immature stages of Diptera Cyclorrhapha. Copenhagen: E.J. Brill/Scandinavian Science Press, pp. 221-719.

GREANY, P.D., 1989. Host plant resistance to tephritids: an under exploited control strategy. In: A.S. ROBINSON and G. HOOPER, eds. Fruit flies: their biology, natural enemies and control. New York: Elsevier, p. 353-362.

GREANY, P.D., STYER, S.C.P., DAVIS, P.L., SHAW, P.E. and CHAMBERS, D.L., 1983. Biochemical resistance of citrus to fruit flies, demonstration and elucidation of resistance to the Caribbean fruit fly, Anastrepha suspensa. Entomologia Experimentalis et Applicata, vol. 34, no. 1, pp. 40-50. http:// dx.doi.org/10.1111/j.1570-7458.1983.tb03288.x.

IOANNOU, C.S., PAPADOPOULOS, N.T., KOULOUSSIS, N.A., TANANAKI, C. and KATSOYANNOS, B., 2012. Essential oils of citrus fruit stimulate oviposition in the Mediterranean fruit fly Ceratitis capitata (Diptera: Tephritidae). Physiological Entomology, vol. 37, no. 4, pp. 330-339. http://dx.doi.org/10.1111/j.13653032.2012.00847.x.

JOACHIM-BRAVO, I.S. and SILVA-NETO, A.M., 2004. Acceptance and preference of fruits for oviposition in two Ceratitis capitata (Diptera, Tephritidae) populations. Iheringia. Série Zoologia, vol. 94, no. 2, pp. 171-176. http://dx.doi.org/10.1590/ S0073-47212004000200009.

LADO, J., RODRIGO, M.J. and ZACARÍAS, L., 2014. Maturity indicators and citrus fruit quality. Stewart Postharvest Review, vol. 10 , no. 2 , pp. 1-6.

LANDOLT, P.J., REED, H.C. and HEATH, R.R., 1992. Attraction of female papaya fruit fly (Diptera, Tephritidae) to male pheromone and host fruit. Environmental Entomology, vol. 21, no. 5, pp. 1154-1159. http://dx.doi.org/10.1093/ee/21.5.1154.

MALEVSKI, Y., BRITO, L.G.Z., PELEG, M. and SILBERG, M., 1977. External color as maturity index of mango. Journal of Food Science, vol. 42, no. 5, pp. 1316-1318. http://dx.doi. org/10.1111/j.1365-2621.1977.tb14486.x.

MARGARITIS, L.H., 1985. Comparative study of the eggshell of the fruit-flies Dacus oleae and Ceratitis capitata (Diptera: Tripeptidae). Canadian Journal of Zoology, vol. 63, no. 9, pp. 2194-2206. http://dx.doi.org/10.1139/z85-324.

MCINNIS, D.O., 1989. Artificial oviposition sphere for Mediterranean fruit flies (Diptera: Tephritidae) in field cages. Journal of Economic Entomology, vol. 82, no. 5, pp. 1382-1385. http://dx.doi.org/10.1093/jee/82.5.1382.

MURILLO, T. and JIRÓN, L.F., 1994. Egg morphology of Anastrepha obliqua and some comparative aspects with eggs of Anastrepha fraterculus (Diptera: Tephritidae). The Florida Entomologist, vol. 77, no. 3, pp. 342-348. http://dx.doi.org/10.2307/3496104.

MUTHUTHANTRI, S. and CLARKE, A.R., 2012. Five commercial citrus rate poorly as hosts of the polyphagous fruit fly Bactrocera tryoni (Froggatt) (Diptera: Tephritidae) in laboratory studies. Australian Journal of Entomology, vol. 51, no. 4, pp. 289-298. http://dx.doi.org/10.1111/j.1440-6055.2012.00866.x.

ONAH, I.E., EYO, J.E. and TAYLOR, D., 2015. Molecular identification of tephritid fruit flies (Diptera: Tephritidae) infesting sweet oranges in Nsukka sgro-ecological zone, Nigeria, based on PCR-RFLP of COI gene and DNA Barcoding. African Entomology, vol. 23, no. 2, pp. 342-347. http://dx.doi.org/10.4001/003.023.0225.

PAIVA, P.E.B. and PARRA, J.R.P., 2013. Hidrogenionic potential $(\mathrm{pH})$ of the attractant, trap density and control threshold for
Ceratitis capitata (Diptera: Tephritidae) on Hamlin oranges in São Paulo central region, Brazil. Revista Brasileira de Fruticultura, vol. 35, no. 2, pp. 464-470. http://dx.doi.org/10.1590/S010029452013000200015

PAPACHRISTOS, D.P. and PAPADOPOULOS, N.K., 2009. Are citrus species favorable hosts for the Mediterranean fruit fly? A demographic perspective. Entomologia Experimentalis et Applicata, vol. 132, no. 1, pp. 1-12. http://dx.doi.org/10.1111/j.15707458.2009.00861.x.

PAPACHRISTOS, D.P., KIMBARIS, A.C., PAPADOPOULOS, N.T. and POLISSIOU, M.G., 2009. Toxicity of citrus essential oils against Ceratitis capitata (Diptera: Tephritidae) larvae. Annals of Applied Biology, vol. 155, no. 3, pp. 381-389. http://dx.doi. org/10.1111/j.1744-7348.2009.00350.x.

PERONDINI, A.L., SELIVON, D. and MORGANTE, J.S., 1998. Facultative polar extrusion of yolk masses and of hatching at the posterior egg pole in Tephritid fruit flies (Diptera). Journal of Insect Morphology and Embryology, vol. 27, no. 3, pp. 249-254. http://dx.doi.org/10.1016/S0020-7322(98)00017-8.

PROKOPY, R.J. and VARGAS, R.I., 1996. Attraction of Ceratitis capitata (Diptera: Tephritidae) flies to odor of coffee fruit. Journal of Chemical Ecology, vol. 22, no. 4, pp. 807-820. PMid:24227587. http://dx.doi.org/10.1007/BF02033588.

QUILICI, S., ATIAMA-NURBEL, T. and BRÉVAULT, T., 2014. Plant odors as fruit fly attractants. In: T. SHELLY, N. EPSKY, E.B. JANG, J. REYES-FLORES and R. VARGAS, eds. Trapping and the detection, control, and regulation of Tephritid fruit flies. Dordrecht: Springer Netherlands, pp. 119-144.

RATTANAPUN, W., AMORNSAK, W. and CLARKE, A.R., 2009. Bactrocera dorsalis preference for and performance on two mango varieties at three stages of ripeness. Entomologia Experimentalis et Applicata, vol. 131, no. 3, pp. 243-253. http:// dx.doi.org/10.1111/j.1570-7458.2009.00850.x.

RATTANAPUN, W., AMORNSAK, W. and CLARKE, A.R., 2010. Is a mango just a mango? Testing within-fruit oviposition site choice and larval performance of a highly polyphagous fruit fly. Arthropod-Plant Interactions, vol. 4, no. 1, pp. 35-44. http:// dx.doi.org/10.1007/s11829-009-9083-6.

SALVATORE, A., BORKOSKY, S., WILLINK, E. and BARDÓN, A., 2004. Toxic effects of lemon peel constituents on Ceratitis capitata. Journal of Chemical Ecology, vol. 30, no. 2, pp. 323-333. PMid:15112727. http://dx.doi.org/10.1023/ B:JOEC.0000017980.66124.d1.

SELIVON, D., MORGANTE, J.S., RIBEIRO, A.F. and PERONDINI, A.L.P., 1996. Extrusion of masses of yolk during embryonary development of the fruit fly Anastrepha fraterculus. Invertebrate Reproduction \& Development, vol. 29, no. 1, pp. 1-7. http://dx.doi. org/10.1080/07924259.1996.9672489.

SEO, S.T., TANG, C.S., SANIDAD, S. and TAKENAKA, T.H., 1983. Hawaiian fruit flies (Diptera: Tephritidae): variation of index of infestation with benzyl isothiocyanate concentration and color of maturing papaya. Journal of Economic Entomology, vol. 76, no. 3, pp. 535-538. http://dx.doi.org/10.1093/jee/76.3.535.

SILVA, F.F., MEIRELLES, R.N., REDAELLI, L.R. and DAL SOGLIO, F.K., 2006. Diversity of flies (Diptera: Tephritidae and Lonchaeidae) in organic citrus orchards in the Vale do Rio Caí, Rio Grande do Sul, Southern Brazil. Neotropical Entomology, vol. 35, no. 5, pp. 666-670. PMid:17144140. http://dx.doi.org/10.1590/ S1519-566X2006000500015. 